\title{
Malignancies Confined to Disused Arteriovenous Fistulae in Renal Transplant Patients: An Important Differential Diagnosis
}

\author{
Philip Webster $^{\mathrm{a}} \quad$ Lareina Wujanto $^{\mathrm{a}}$ Cyril Fisher $^{\mathrm{b}} \quad$ Marjorie Walker $^{\mathrm{a}}$ \\ Rathi Ramakrishnan $^{\mathrm{a}}$ Kikkeri Naresh $^{\mathrm{a}} \quad$ J. Meirion Thomas ${ }^{\mathrm{b}}$ Vassilios Papalois $^{\mathrm{a}}$ \\ Jeremy Crane ${ }^{a}$ David Taube $^{a}$ Neill Duncan ${ }^{a}$ \\ a Imperial College Healthcare NHS Trust, and ${ }^{\mathrm{b}}$ The Royal Marsden NHS Trust, London, UK
}

Key Words

Transplantation · Fistula • Malignancy

\begin{abstract}
Background: Swelling in an arteriovenous fistula (AVF) is commonly caused by thrombosis, aneurysm and infection. However, due to the increased risk of malignancy after transplantation, this should also be considered. Patients: We discuss 4 patients with malignancy confined to an AVF after renal transplantation presenting in a 2-year period. Angiosarcoma was diagnosed in 3 patients and the other had posttransplant lymphoproliferative disorder (PTLD). Angiosarcoma behaves aggressively and 2 of our patients died within 6 months of diagnosis. There are 6 previous cases and 5 died within 16 months of diagnosis. PTLD at AVFs has not been documented previously. Conclusion: Malignancy at an AVF is a rare but important differential that can impact significantly on patient morbidity and mortality. Predilection for malignancy at an AVF is not understood. We review the literature and discuss possible aetiologies.
\end{abstract}

Copyright ๑ 2011 S. Karger AG, Basel

\section{Introduction}

Malignancy after solid organ transplantation poses a significant burden with a standardised incidence ratio of 3.27 [1]. Skin cancers represent the most common de novo malignancy after renal transplantation and they behave more aggressively with a higher chance of reoccurrence and metastasis. There has been an exponential rise in squamous cell carcinoma in patients with solid organ transplants, and although malignant melanoma is the least likely skin malignancy in these patients, it is still twice as common as in the general population [2]. We discuss an interesting series of 4 patients with rare cutaneous presentations of cancers confined within an arteriovenous fistula (AVF) previously used for haemodialysis.

\section{Angiosarcoma}

Case 1

A 59-year-old Caucasian male developed proliferative glomerulonephritis secondary to Alport's syndrome in 1992. He developed an Epstein-Barr virus-driven post-

Tel. +44208383 5843, E-Mail p.webster@imperial.ac.uk 

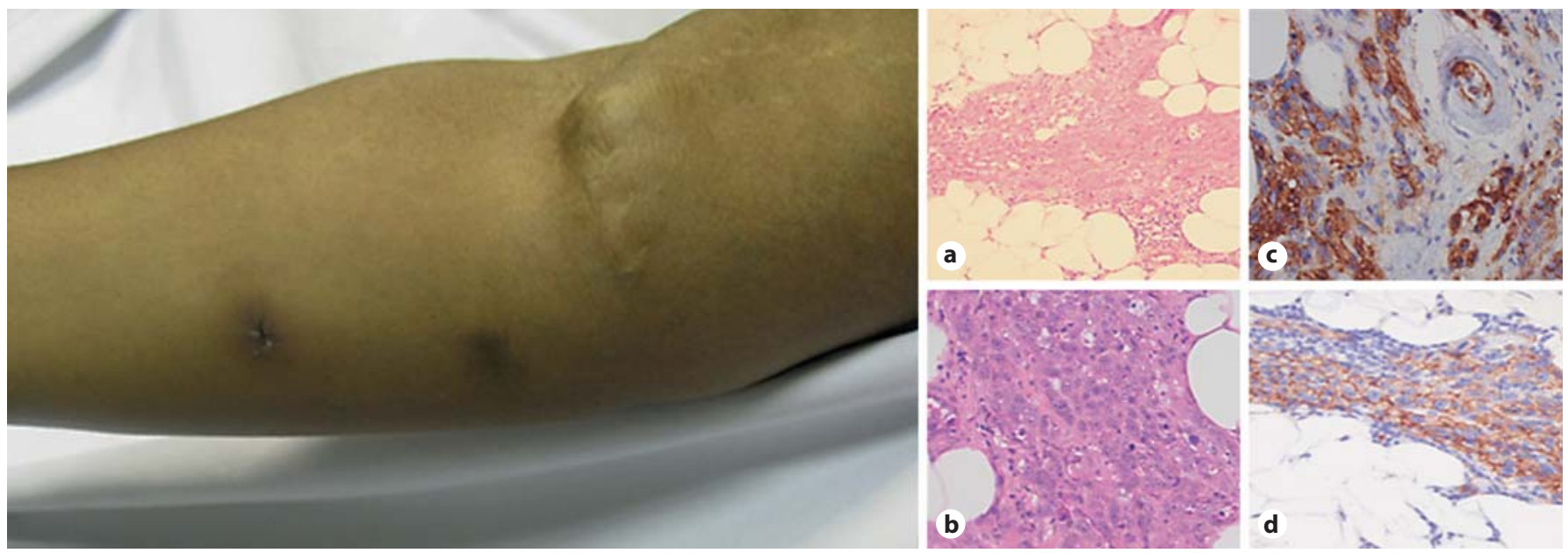

Fig. 1. Left: angiosarcoma confined to the AV fistula of a renal transplant patient (case 2). Note the dusky lesions distal to the fistula. Right: histology of the same patient with angiosarcoma (case 2). Within the deep dermis and along the fascial planes there is an infiltrate of epithelioid pleomorphic cells with prominent nucleoli and a high mitotic rate $(\mathbf{a}, \mathbf{b})$ which are positive by immunocytochemistry for CD31 (c, d). $257 \times 84 \mathrm{~mm}(300 \times$ 300 DPI).

immunosuppression lymphoproliferative disease in 2001 associated with mycophenolate mofetil (MMF). This responded to aciclovir and immunosuppression withdrawal. He started haemodialysis via a right arm brachiocephalic AVF in 2005. He received a live-unrelated, ABOincompatible renal transplant in 2006 (B into O; 2, 1, 1 mismatch). Desensitisation was achieved with plasma exchange, rituximab $(1 \mathrm{~g} \times 2)$ and daclizumab $(2 \mathrm{mg} / \mathrm{kg}$ $\times 2)$. Immunosuppression was maintained with tacrolimus. In 2008, he presented with pain and swelling in his AVF which was attributed to thrombosis and infection. The fistula was excised in July 2008. Histology showed a $5.5 \times 6 \times 4 \mathrm{~cm}$ epithelioid angiosarcoma. There were atypical, large, polygonal epithelioid cells displaying endothelial markers and cytokeratin. The cells stained diffusely positive for CD31 and CD34, focally positive for MNF116, CK18, CK7 and EMA, and negative for CD20, CD3, CD30, light chains, EBER, HHV8 and CMV. He had an above elbow amputation in September 2008. He remains well with no metastasis and good transplant function. The surgical management of this case has previously been reported [3].

\section{Case 2}

A 41-year-old Afro-Caribbean female with end-stage renal failure secondary to reflux nephropathy and secondary focal segmental glomerulosclerosis started haemodialysis via a right arm brachiocephalic AVF in 2003. She received a live-related renal transplant in 2006, with alemtuzumab $(30 \mathrm{mg})$ and methylprednisolone at induction and tacrolimus as maintenance immunosuppression. In 2009, she presented with pain at the AVF. MRI showed a thrombosed fistula but also bone oedema and abnormal signalling in the ulna. One month later she developed dusky, purple, palpable, non-tender cutaneous and subcutaneous nodules, measuring $1 \mathrm{~cm}$ in diameter, all distal to the AVF (fig. 1). Biopsy revealed an epithelioid angiosarcoma (fig. 1) with an infiltrate of epithelioid pleomorphic cells with prominent nucleoli and a high mitotic rate at the level of the deep dermis. Immunohistochemistry showed positivity for CD31, focal positivity for CD34, and negative for S100, MelanA, EMA, MNF116, CD45 and CEA. All microbiology was negative. She developed lung metastases and died 4 months after presentation.

\section{Case 3}

A 44-year-old male with end-stage renal failure secondary to polycystic kidney disease started haemodialysis via a left arm brachiocephalic AVF in 1997. In 2002, he received a cadaveric transplant (1, 1, 0 mismatch). Induction immunosuppression was with methylprednisolone and maintenance therapy included tacrolimus and MMF. In March 2010, he presented with a painful, enlarging mass at the AVF with warts overlying the fistula. Initial biopsy was inconclusive showing possible $\mathrm{T}$ cell lymphoproliferative change. Serum Epstein-Barr virus levels were 7,200 copies per milliliter. MMF was stopped 
and the fistula was closely observed. A repeat biopsy in June 2010 showed epithelioid angiosarcoma. Vessel walls showed plump, atypical epithelioid endothelial cells with mitoses. They were positive for CD31 and focally positive for CD34. They were negative for CD20, CD30, EBER and human herpes virus 8 . He developed lung metastases and died within 6 months of presentation.

\section{Background}

Cutaneous soft tissue sarcomas are rare. The American Cancer Society reported 12,114 cases between 1992 and 2004 covering 13 American Registries (14\% of the population) which was the first large population-based study [4]. Angiosarcoma accounted for $1.6 \%$ and was found to be most common in Caucasians with an exponential rise over the last 30 years and a relative 5 -year survival rate of $45 \%$. It occurs anywhere in the body but most commonly in chronically sun-damaged skin, postirradiation and in chronically lymphoedematous limbs, e.g. after breast cancer (Stewart-Treves syndrome). It also occurs after exposure to toxins, e.g. vinyl chloride. Angiosarcoma is a rare complication of immunosuppression in renal transplant patients. It has presented in the legs, scalp, renal transplant and abdominal wall. There is also documentation of angiosarcoma confined to a non-iatrogenic AVF in the lymphoedematous arm of a non-immunosuppressed patient [5].

\section{Histology}

The epithelioid phenotype of angiosarcoma was first described in cases of cutaneous angiosarcoma in 1976 [6]. Epithelioid angiosarcoma is a rare, rapidly growing malignant vascular tumour which behaves aggressively and has insidious progression. It is characterised by sheets of highly atypical large rounded cells with prominent eosinophilic nucleoli, in which the only morphological evidence of vascular differentiation may be the presence of occasional intracytoplasmic vacuoles. Cytokeratin positivity is present in one-third, making distinction from carcinoma problematic. Fortunately this distinction can be demonstrated by coexistent CD31 (platelet-endothelial cell adhesion molecule) expression, which is the most sensitive and specific antigen for endothelial differentiation [7].

\section{Treatment}

Management remains extremely difficult. Surgery offers the only chance of cure in a patient with no metastasis. The role of adjuvant chemotherapy offers no benefit to survival. Radiation provides local benefit prior to sur- gery. Doxorubicin chemotherapy may be indicated in metastatic or unresectable disease.

\section{Previous Cases}

There are no similar cases described in patients who are not immunosuppressed. There are 6 similar previous cases (table 1, cases A-F) [8-14]. Case F was published twice. All 6 cases presented with swelling at the AVF with or without pain and all were thought to be thrombosed aneurysms. All patients were heavily immunosuppressed. Cases A, D and E had multiple transplants. Cases D and E were treated for rejection. Case F had azathioprine toxicity at the time of presentation.

Tumour size was indicated in 4 cases and all were significant at the time of presentation. The smallest was 3.5 $\times 3.5 \mathrm{~cm}$ (case 2) and the largest was $18 \times 7 \times 6.5 \mathrm{~cm}$ (case 4). Case 3 did not include measurements, but a photograph revealed an obvious forearm mass. Case 5 did not indicate size. Histology revealed epithelioid cells in all cases. No further detail was discussed in case 5 . All other cases described plump cells with large nuclei. Cases 1, 2 and 3 were positive for CD31 cytokeratin.

\section{Post-Transplant Lymphoproliferative Disease}

\section{Case 4}

A 56-year-old male with end-stage renal failure secondary to hypertension started haemodialysis via a left arm brachiocephalic AVF in 1997. He had a cadaveric transplant in 1998 (2 antigen mismatch). He received methylprednisolone at induction with tacrolimus and prednisolone for maintenance. In 2007, he was treated with MMF and augmented steroids for cellular rejection. In March 2010, he presented with swelling over the AVF. Biopsy showed post-transplant lymphoproliferative disorder (PTLD) with features of diffuse large B cell lymphoma (fig. 2). The lymphoid cells expressed CD20, CD79a, CD30 and EBV-LMP1. MMF has been stopped and he is currently undergoing treatment with rituximab monotherapy.

\section{Background}

PTLD is a lymphoid proliferation that develops as a complication of immunosuppression after solid organ or bone marrow transplantation. It represents a spectrum of disease and is the second most common posttransplant malignancy in those receiving renal allografts. Eighty-five percent are B cell in origin and there is a $50 \%$ mortality [15]. Most cases present in the 
Table 1. Previous cases of cutaneous angiosarcoma limited to haemodialysis arteriovenous fistulae in renal transplant patients

\begin{tabular}{|c|c|c|c|c|c|c|c|c|}
\hline Case & Authors & $\begin{array}{l}\text { Age } \\
\text { years }\end{array}$ & Sex & $\begin{array}{l}\text { Immuno- } \\
\text { suppression }\end{array}$ & $\begin{array}{l}\text { Time from } \\
\text { transplant to } \\
\text { diagnosis of AS }\end{array}$ & $\begin{array}{l}\text { Time from } \\
\text { diagnosis of AS to } \\
\text { diagnosis of mets }\end{array}$ & Treatment & $\begin{array}{l}\text { Time from } \\
\text { diagnosis of } \\
\text { AS to death }\end{array}$ \\
\hline $\mathrm{A}$ & Farag et al. [8] & 39 & $\mathrm{M}$ & $\begin{array}{l}\text { cyclosporin } \\
\text { azathioprine } \\
\text { steroids }\end{array}$ & 10 years & at diagnosis & $\begin{array}{l}\text { resection } \times 2 \text {; } \\
\text { adriamycin and } \\
\text { paclitaxel for mets }\end{array}$ & 11 months \\
\hline B & Wehrli et al. [9] & 74 & $\mathrm{M}$ & $\begin{array}{l}\text { cyclosporin } \\
\text { azathioprine } \\
\text { steroids }\end{array}$ & 7 years & at diagnosis & $\begin{array}{l}\text { limb amputation; } \\
\text { radiotherapy }\end{array}$ & $\begin{array}{l}\text { still alive with } \\
\text { lung mets } \\
6 \text { months } \\
\text { post-diagnosis }\end{array}$ \\
\hline $\mathrm{C}$ & Bessiss et al. [10] & 68 & M & $\begin{array}{l}\text { cyclosporin } \\
\text { azathioprine } \\
\text { steroids }\end{array}$ & 7 years & 7 months & limb amputation & 7 months \\
\hline $\mathrm{D}$ & Conlon et al. [11] & 40 & M & $\begin{array}{l}\text { azathioprine } \\
\text { steroids }\end{array}$ & 7 years & 3 months & $\begin{array}{l}\text { skeletalization resec- } \\
\text { tion; radiotherapy; } \\
\text { chemotherapy for mets }\end{array}$ & 5 months \\
\hline $\mathrm{E}$ & Keane et al. [12] & 41 & M & $\begin{array}{l}\text { cyclosporin } \\
\text { azathioprine } \\
\text { steroids }\end{array}$ & 7 years & 2 months & $\begin{array}{l}\text { wide excision; radio- } \\
\text { therapy; ifosfamide, } \\
\text { etoposide, vincristine, } \\
\text { doxorubicin and } \\
\text { cyclophosphamide }\end{array}$ & 8 months \\
\hline \multirow[t]{4}{*}{$\mathrm{F}$} & $\begin{array}{l}\text { Byers et al. [13], } \\
\text { Parrott et al. [14] }\end{array}$ & 36 & M & $\begin{array}{l}\text { cyclosporin } \\
\text { azathioprine } \\
\text { steroids }\end{array}$ & 8 years & 16 months & amputation & 16 months \\
\hline & This paper, case 1 & 59 & M & $\begin{array}{l}\text { rituximab } \\
\text { daclizumab } \\
\text { tacrolimus }\end{array}$ & 2 years & no mets & amputation & still alive \\
\hline & This paper, case 2 & 41 & $\mathrm{~F}$ & $\begin{array}{l}\text { alemtuzumab } \\
\text { tacrolimus }\end{array}$ & 3 years & 2 months & supportive & 4 months \\
\hline & This paper, case 3 & 44 & M & $\begin{array}{l}\text { tacrolimus } \\
\text { MMF } \\
\text { steroids }\end{array}$ & 8 years & no mets & $\begin{array}{l}\text { immunosuppression } \\
\text { reduction; supportive }\end{array}$ & 6 months \\
\hline
\end{tabular}

AS = Angiosarcoma mets = metastases MMF = mycophenolate mofetil.

gastrointestinal tract, liver, kidney or lymph nodes, but PTLD has been reported in the skin. The aetiology is multifactorial, but Epstein-Barr virus (EBV) infection and chronic immunosuppression are both well recognized. EBV remains latent in memory B cells after primary infection. Cellular immune response controls both primary and latent infection. After immunosuppression, primary infection or reactivation of latent EBV is followed by an inadequate $\mathrm{T}$ cell immune response. The latent EBV genome can be detected in EBV-related lymphomas. The more intense the immunosuppression used, especially from high doses of anti-T cell immuno- suppressive agents, the higher the incidence of PTLD and the earlier it occurs, hence most EBV-related PTLD is in the first year post-transplant. There are several case reports of cutaneous PTLD [16]. Cutaneous presentations are variable and can range from erythematous plaques to ulcerated nodules, occurring in isolation or more generalized. There are no previous cases reported to be confined to an AVF.

\section{Histology}

Histopathological findings of PTLD are varied. There are 4 subtypes in the WHO classification. Early PTLD is 

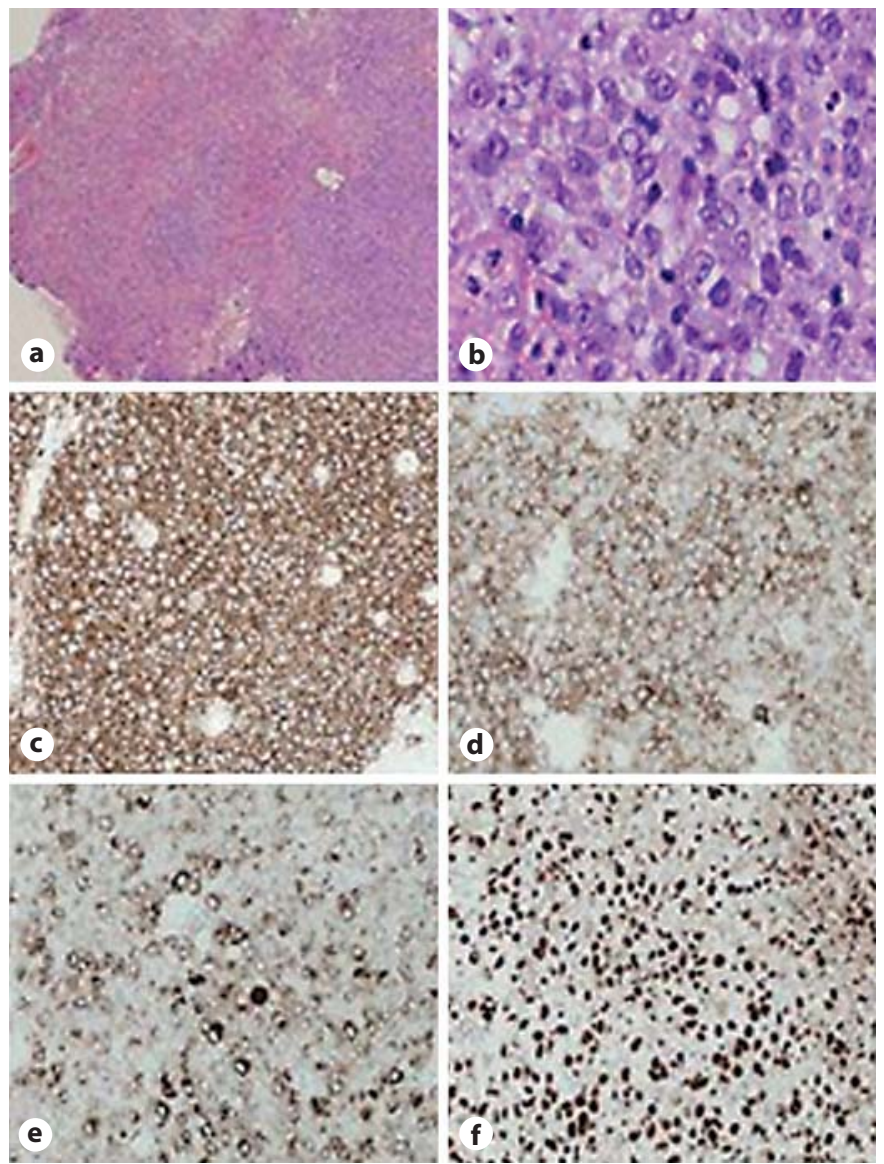

Fig. 2. Biopsy from the post-transplant lymphoproliferative disorder shows an ulcerated lesion with necrosis (a). Cellular areas composed of sheets of large nucleolated lymphoid cells (b). Tumour cells were positive for CD20 (c), CD30 (d), EBV (e) and $\operatorname{EBER}(\mathbf{f}) .70 \times 97 \mathrm{~mm}(300 \times 300 \mathrm{DPI})$.

polyclonal and includes reactive plasmacytic hyperplasia and infectious mononucleosis-like PTLD. Polymorphic PTLD may be polyclonal or monoclonal. Monomorphic PTLD is monoclonal of $\mathrm{B}$ or T cell lineage. The final class is Hodgkin's lymphoma-type PTLD.

Cases involving the skin present mostly with the features of diffuse large B-cell lymphoma. Cellular markers are vital in determining cell lineage. B-cells possess CD19, CD20, CD72, and CD79a, and T cells show CD2 and CD3. CD45 may be found on both $\mathrm{T}$ and $\mathrm{B}$ cell lineages [17]. CD30, expressed in several anaplastic lymphoproliferative disorders, is found to be upregulated in EBVtransformed B cells. Several of these markers can be either upregulated or downregulated in the abnormal cells of PTLD, hence the importance of a diverse panel of antibodies for diagnostic accuracy.

\section{Treatment}

Reduction of immunosuppression may allow complete remission of PTLD but is associated with a higher incidence of graft rejection and loss. Aciclovir prevents EBV viral replication. If given at the appropriate time interval this may reduce infection of recipient $B$ cells; however, it will not affect the latent virus and so is of limited use in treating established PTLD. Interferon- $\alpha$ has been used with some success but is associated with a higher incidence of graft rejection. Localised PTLD and local complications of PTLD may be treated with radiotherapy and surgery [18]. Rituximab and CHOP regime chemotherapy have been used with success and may even help to negate the higher incidence of rejection associated with immunosuppression reduction through their immunosuppressive effects [19].

\section{Discussion}

There are many reasons why a patient with renal failure may develop malignancy. Uraemia leads to immune dysfunction due to impaired $\mathrm{T}$ and $\mathrm{B}$ cell signalling [20]. These patients may also retain carcinogens and have nutritional disturbances [21]. Immunosuppression impairs immune surveillance by natural killer cells and clearance of early malignant cells. Calcineurin inhibitors may facilitate aberrant cytokine production, e.g. transforming growth factor beta and vascular endothelial growth factor, which promotes angiogenesis, tumour growth and metastasis [22]. Viruses are well established in the aetiology of some malignancies, and our patient with PTLD was positive for EBV-LMP1. Many malignancies with increased incidence after renal transplantation have established viral aetiology, whilst the incidences of the most common malignancies in the general population are only modestly elevated [1]. This is thought to be due to disrupted anti-viral immune activity secondary to immunosuppression. With regard to angiosarcoma, it can copresent with HHV-8-driven Kaposi's sarcoma and there are several case reports of HHV-8 positivity in those with angiosarcoma. However, despite this seeming very possible, a direct link has never been proven and warrants further research [23].

Predilection for malignancy at the site of an AVF is not understood. Possible mechanisms include:

- Increased venous pressure at the AVF increases lymphatic workload and reduces lymphatic drainage. This may impair local immune responses [24]. 
- Oscillatory blood flow (in contrast to laminar flow) causes shear stress at the endothelium providing a proinflammatory stimulus to upregulate growth peptides (e.g. vascular cell adhesion molecule-1) and their receptors [25].

- Oscillatory blood flow in AVFs has been found to enhance the activity of the DNA transcription regulator 'nuclear factor kappa light-chain enhancer of activated $B$ cells' (NF- $\kappa$ B) by phosphorylation. This was associated with increased production of reactive oxygen species and matrix metalloproteinase (MMP)-9 giving a heightened proliferative response to allow vascular remodelling. These effects were diminished in cells and mice treated with NF- $\kappa \mathrm{B}$ inhibitor [26]. MMP-9 is physiologically involved in extracellular matrix remodelling. Interestingly, overactivity has been implicated in more aggressive lymphomas [27] and soft tissue sarcomas [28].

- Tumours often have marked areas of hypoxia as rapid cell proliferation exceeds the capacity of the oxygen supply. A subsequent elevation of hypoxia inducible factor- $1 \alpha$ has been found to induce T cell suppression leading to a diminished immune response [29]. An AVF causes limb hypoperfusion and this relative ischaemia has been proposed as a possible mechanism of cancer occurrence in the fistula arm [30].

\section{Conclusion}

Malignancy should be considered when a patient presents with new symptoms at an AVF. Examination of disused AVFs should be performed routinely in the transplant outpatient setting. Clinicians should be alerted to a change in size, persistent pain, skin changes (overlying, proximal or distal to the AVF) and cessation of fistula function. Close follow-up of any change is essential. Prompt imaging (initially by ultrasound followed by more detailed cross-sectional imaging) is crucial and should guide consideration of biopsy to allow early diagnosis to limit morbidity and mortality. Case 3 illustrates the importance of obtaining an appropriate tissue sample to make an accurate diagnosis. This rare complication has previously been reported, but we believe our 4 cases in a short time period may represent an increasing burden in a population where cancer incidence is escalating. The pathogenesis for predilection at a fistula site warrants further research.

\section{Disclosure Statement}

None.

\section{References}

1 Vajdic CM, McDonald SP, McCredie MRE: Cancer incidence before and after kidney transplantation. JAMA 2006;296:28232831.

-2 Euvrard S, Kanitakis J, Claudy A: Skin cancers after organ transplantation. N Engl J Med 2003;348:1681-1691.

-3 Qureshi YA, Strauss DC, Thway K, Fisher C, Thomas JM: Angiosarcoma developing in a non-functioning arteriovenous fistula postrenal transplant. J Surg Oncol 2010;101:520523.

-4 Rouhani P, Fletcher CD, Devesa SS, Toro JR: Cutaneous soft tissue sarcoma incidence patterns in the US: an analysis of 12,114 cases. Cancer 2008;113:616-627.

5 Faggioli GL, Bertoni F, Bacchini P, Stella A, Gessaroli M, Gargiulo M: Angiosarcoma in a limb with arteriovenous fistulas and elephantiasis. Int Angiol 1989;8:161-170.

-6 Rosai J, Sumner HW, Kostianovsky M, Perez-Mesa C: Angiosarcoma of the skin: a clinicopathologic and fine structural study. Hum Pathol 1976;7:83-109.
7 Ohsawa M, Naka N, Tomita Y, Kawamori D, Kanno H, Aozasa K: Use of immunohistochemical procedures in diagnosing angiosarcoma: evaluation of 98 cases. Cancer 1995; 75:2867-2874

-8 Farag R, SchulakJA, Abdul-Karim FW, Wasman JK: Angiosarcoma arising in an arteriovenous fistula in a renal transplant patient: a case report and literature review. Clin Nephrol 2005;63:408-412.

$\checkmark 9$ Wehrli BM, Janzen DL, Shokeir O, Masri BA Byrne SK, O’Connell JX: Epithelioid angiosarcoma arising in a surgically constructed arteriovenous fistula: a rare complication of chronic immunosuppression in the setting of renal transplantation. Am J Surg Pathol 1998:22:1154-1159.

10 Bessiss D, Sotto A, Roubert P, Chabrier PE, Mourad G, Guilhou JJ: Endothelin-secreting angiosarcoma occurring at the site of an arteriovenous fistula for haemodialysis in a renal transplant recipient. Br J Dermatol 1998; 138:361-263.
11 Conlon PJ, Daly T, Doyle G, Carmody M: Angiosarcoma at the site of a ligated arteriovenous fistula in a renal transplant recipient. Nephrol Dial Transplant 1993;8:259-262.

12 Keane MM, Carney DN: Angiosarcoma arising from a defunctionalized arteriovenous fistula. J Urol 1993;149:364-365.

13 Byers RJ, McMahon RF, Freemont AJ, Parrott NR, Newstead CG: Epithelioid angiosarcoma arising in an arteriovenous fistula. Histopathology 1992;21:87-89.

14 Parrott NR, Scott PD, Freemont AJ, Johnson RW: Angiosarcoma in an arteriovenous fistula following successful renal transplantation - a case report. Transplantation 1993;55: 676-677.

15 Parker A, Bowles K, Bradley JA, et al: Diagnosis of post-transplant lymphoproliferative disorder in solid organ transplant recipients - BCSH and BTS Guidelines. Br J Haem 2010;149:675-692.

16 Salama S, Todd S, Cina DP, Margetts P: Cutaneous presentation of post-renal transplant lymphoproliferative disorder: a series of four cases. J Cutan Pathol 2010;37:641653. 
17 Snavely NR, Sonabend M, Rosen T: Post transplant Epstein-Barr virus related lymphoproliferative disorder with a primary cutaneous presentation. Dermatol Online J 2007;13:4.

18 Gottschalk S, Rooney CM, Heslop HE: Posttransplant lymphoproliferative disorders. Annu Rev Med 2005;56:29-44.

19 Trappe R, Hinrichs C, Appel U, et al: Treatment of PTLD with rituximab and CHOP reduces the risk of renal graft impairment after reduction of immunosuppression. Am J Transplant 2009;9:2331-2337.

20 Girndt M, Sester M, Sester U, Kaul H, Kohler $\mathrm{H}$ : Molecular aspects of T- and B-cell function in uraemia. Kidney Int 2001;59:S206S211.

21 Vamvakas S, Bahner U, Heidland A: Cancer in end-stage renal disease: potential factors involved. Am J Nephrol 1998;18:89-95.

22 Guba M, Graeb C, Jauch KW, Geissler EK: Pro- and anti-cancer effects of immunosuppressive agents used in organ transplantation. Transplantation 2004;77:1777-1782.
23 Schmid H, Zietz C: Human herpesvirus 8 and angiosarcoma: analysis of 40 cases and review of the literature. Pathology 2005;37: 284-287.

-24 Bordea C, Cortina-Borja M, Wojnarowska F, Morris PJ: Distribution of upper limb skin cancers in relation to arteriovenous fistula side in renal transplant recipients. Transplantation 2001;71:143-145.

25 Chappell DC, Varner SE, Nerem RM, Medford RM, Wayne-Alexander R: Oscillatory shear stress stimulates adhesion molecule expression in cultured human endothelium. Circ Res 1998;82:532-539.

26 Castier Y, Ramkhelawon B, Riou S, Tedgui A, Lehoux S: Role of NF- $\kappa \mathrm{B}$ in flow-induced vascular remodelling. Antioxid Redox Signal 2009;11:1641-1649.
27 Alaniz L, Garcia M, Cabrera P, Arnaiz M, Cavaliere V, Blanco G, Alvarez E Hajos S: Modulation of matrix metalloproteinase-9 activity by hyaluronan is dependent on NF$\kappa \mathrm{B}$ activity in lymphoma cell lines with dissimilar invasive behaviour. Biochem Biophys Res Commun 2004;324:736-743.

28 Benassi MS, Gamberi G, Magagnoli G, Molendini L, Ragazzini P, Merli M, Chiesa F, Balladelli A, Manfrini M, Bertoni F, Mercuri M, Picci P: Metalloproteinase expression and prognosis in soft tissue sarcomas. Ann Oncol 2001;12:75-80.

29 Doedens AL, Stockmann C, Rubinstein MP, Liao D, Zhang N, DeNardo DG, Coussens LM, Karin M, Goldrath AW, Johnson RS: Macrophage expression of hypoxia-inducible factor-1 $\alpha$ suppresses T-cell function and promotes tumor progression. Cancer Res 2010;70:7465-7475.

-30 Van Hoek F, Van Tits H, Van Lijnschoten I, De Haas B, Scheltinga M: Multiple carcinomas in the hemodialysis access induced ischemic hand of a renal transplant patient. Eur J Dermatol 2010;20:214-216. 